\title{
PHYTOCHEMICAL, ANTIOXIDANT, AND TRACE ELEMENT ANALYSIS OF ANTHELMINTIC PLANTS OF NORTH-EAST INDIA
}

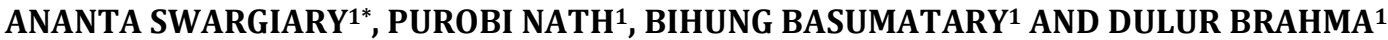 \\ ${ }^{1 *}$ Department of Zoology, Bodoland University, Kokrajhar 783370, Assam, India \\ Email: ananbuzoo101@gmail.com
}

Received: 12 Jun 2017 Revised and Accepted: 22 Jul 2017

\section{ABSTRACT}

Objective: Cynodon dactylon, Hibiscus rosa-sinensis, Elaeocarpus floribundus and Acorus calamus are anthelmintic medicinal plants of north-east India. Due to its pharmacological properties, the present study was aimed to investigate the phytochemical, antioxidant and heavy metal content of the plants.

Methods: Preliminary phytochemical screening was carried out for the presence of phenolics, flavonoids, proteins, and carbohydrates following standard protocols. The antioxidant potential of plants was studied by phosphomolybdate, 1,1-diphenyl-2-picrylhydrazyl (DPPH) and ferric reducing antioxidant power (FRAP) assay. The heavy metal content was estimated using atomic absorption spectrophotometer (Perkin Elmer 3110).

Results: The result showed that the alcoholic extracts of the plant sample contain high quantity of proteins, carbohydrates, phenolics, and flavonoids. Antioxidant assays revealed appreciable free radical scavenging potential. The total antioxidant activity was highest in $E$. floribundus $(62.48 \pm 1.53 \mu \mathrm{g} / \mathrm{mg}$ extract) while $C$. dactylon showed lowest $(34.00 \pm 0.32 \mu \mathrm{g} / \mathrm{mg}$ extract). Similarly, DPPH and FRAP study also showed high in $E$. floribundus and lowest in H. rosa-sinensis and A. calamus. Elemental analysis of the plant extracts showed a high content of Mn in all the plants while Co was found to be lowest. The tested plants showed low levels of toxic elements.

Conclusion: The high quantity of nutritional content and antioxidant property suggest that plants may be a good source of phytomedicine. Less quantity of toxic elements offers an opportunity to explore the medicinal application of the plants. However, further study needs to be carried out to know its mode of action.

Keywords: Anthelmintic plants, Phytochemicals, Antioxidant, Trace elements

(C) 2017 The Authors. Published by Innovare Academic Sciences Pvt Ltd. This is an open access article under the CC BY license (http://creativecommons.org/licenses/by/4.0/D DOI: http://dx.doi.org/10.22159/ijpps.2017v9i9.20668

\section{INTRODUCTION}

Traditionally used medicinal plants have been the source of health care system in rural India since ancient times including the northeastern (NE) region. In this part of India, several wild plants and herbs are found to be used as medicine against many health complications such as heart attack, cancer, diabetes, malaria, jaundice, wound healing, microbial infections, helmintic infections, inflammation, etc [1]. The use and attention towards ethno medicines and their scientific validation keep growing due to its innumerable medical significances and absence of undesirable sideeffects. The various medicinal properties present in a plant can be attributed to the diversities of phytochemicals present in the plant. Antioxidant is an important property by which living organisms can neutralize the toxic and cell-damaging molecules called free radicals which are generated during various metabolic reactions of the body. Free radicals can generate either from normal cell metabolisms in situ or from external sources such as pollution, cigarette smoke, radiation, medication etc. In addition, a by-product of oxidative phosphorylation called reactive oxygen species (ROS) is also a free radical, the accumulation of which can lead to many chronic and degenerative diseases like cancer, autoimmune disorders, aging, cataract, rheumatoid arthritis, cardiovascular and neurodegenerative diseases [2]. Various antioxidant molecules or enzymes have the potential to exert their biological activity and scavenge ROS by quenching chain initiating catalysis, metal ion chelation, co-antioxidants, or by gene expression regulation $[3,4]$.

Mineral elements play vital functions in the body which include components of structural proteins, cofactors and activator of enzymes, regulators of nerve transmission, muscle contraction, osmotic pressure and salt-water balance etc. [5]. It has been reported that metals such as cobalt, copper, chromium, iron, magnesium, manganese, molybdenum, nickel, selenium, zinc, etc. are essential nutrients required for various biochemical and physiological functions. Inadequate supply of these micro-nutrients results in a variety of deficiency diseases or syndromes [6]. Several scientific studies have also proved that plants are a good source of trace elements and micronutrients. However, the presence of certain heavy metals such as cadmium, lead etc. are toxic to human body affecting multiple health complications including kidney, bone, neurobehavioral and developmental disorders, high blood pressure and cancer $[7,8]$. In view of these facts, several studies have been conducted around the world to ensure plants as an alternative and safe source of antioxidant and micronutrients. In a recent study, Acorus calamus Linn. and Hibiscus rosa-sinensis L., showed significant anthelmintic activity against the cestode parasite, Hymenolepis diminuta $[9,10]$. Cynodon dactylon L. Pers and Elaeocarpus floribundus also showed anthelmintic efficacy against Hymenolepis diminuta, both in vitro and in vivo. [11].

Acorus calamus Linn. (Acoraceae) commonly known as the sweet flag is a perennial herb possessing numerous medicinal properties and have been widely used against several health complications such as diarrhea, bronchial catarrh, fevers, cough, asthma etc [12, 13]. A plethora of literature revealed the biological property of the plant such as antimicrobial, insecticidal etc. and several phytochemicals like $\alpha$-asarone, (E)-methyl Isoeugenol, methyleugenol, $\beta$-asarone, $\alpha$-cedrene have been isolated $[14,15]$.

Hibiscus rosa-sinensis L. belonging to the family Malvaceae is a popular medicinal plant of $\mathrm{NE}$ region used against diseases like dysentery, diarrhea, fever, cough and several others $[10,16]$. Cynodon dactylon (L.) Pers belonging to the family Poaceae, commonly known as Bermuda grass is known for several biological activities such as antimicrobial, antiviral, antioxidant, antidiabetic, hypolipidemic and hepatoprotective effects and phytochemicals like apigenin, luteolin, 6-C-pentosyl-8-C-hexosyl apigenin etc. have been 
reported from the plant [17]. Elaeocarpus floribundus (Elaeocarpaceae) is a plant that grows well in lowland hills and mountains of India, Burma, Thailand, Vietnam, Malaysia and Indonesia [18]. Along with the traditional use of the plant for making pickles, it is also used as anthelmintics against helminth infections in $\mathrm{NE}$ region. In view of medicinal properties, the present study has attempted to study the phytochemical, antioxidant and trace element of Acorus calamus, Hibiscus rosa-sinensis, Cynodon dactylon and Elaeocarpus floribundus.

\section{MATERIALS AND METHODS}

\section{Chemicals and drugs}

Ascorbic acid; gallic acid; quercetin; aluminum chloride $\left(\mathrm{AlCl}_{3}\right)$; ferric chloride $\left(\mathrm{FeCl}_{3}\right)$; folin-Ciocalteu; bovine serum albumin (BSA); oxalic acid; 1,1-diphenyl-2-picrylhydrazyl (DPPH); thiobarbituric acid (TBA); trichloroacetic acid (TCA); 2,4,6-tripyridyl-s-triazine (TPTZ); sulphuric acid; hydrochloric acid; ammonium molybdate; potassium ferricyanide $\left[\mathrm{K}_{3} \mathrm{Fe}(\mathrm{CN})_{6}\right]$; chloroform and alcohols were purchased from Himedia and SRL (India). All chemicals used were analytical grade.

\section{Collection, identification, and preparation of crude extract of plants}

Acorus calamus Linn. (rhizomes), Hibiscus rosa-sinensis L. (leaves), Cynodon dactylon L. Pers (whole plant) and Elaeocarpus floribundus (leaves) were collected from three different districts of Tripura, India. Prior permission was taken from the local heads for the collection of the plants. The collected plant materials were washed with tap water and air dried at room temperature. All the dried plant materials were ground to powder and extracted using soxhlet extractor at $40{ }^{\circ} \mathrm{C}$ for $4-5 \mathrm{~h}$. The process was repeated for three times and the filtrate obtained was evaporated in a rotary evaporator. Dry, semi-solid extracts (crude extract) were kept in plastic vials at $4{ }^{\circ} \mathrm{C}$ for further use.

\section{Phytochemical study \\ Carbohydrate}

The presence of total carbohydrate content of plant extract was estimated following the anthrone method as described by [19]. Values were expressed as $\mu \mathrm{g} / \mathrm{mg}$ plant extract using the calibration curve of glucose.

\section{Protein}

The protein content of all the plant extracts was estimated following the method of [20]. Values were expressed as $\mu \mathrm{g}$ protein/mg plant extract using the calibration curve of BSA.

\section{Total phenolic content (TPC)}

The TPC of all the four plant extracts was estimated using folinciocalteu reagent and sodium carbonate [21]. The amount of TPC was calculated from a calibration curve of gallic acid and the results were expressed as $\mu$ g gallic acid equivalent (GAE)/mg plant extract.

\section{Total flavonoid content (TFC)}

The flavonoid content of the plant was determined by the formation of yellow color using the $\mathrm{AlCl}_{3}$ method of [22]. The TFC was calculated from the standard curve of quercetin and the values were represented as $\mu \mathrm{g}$ quercetin equivalent $(\mathrm{QE}) / \mathrm{mg}$ plant extract.

\section{Antioxidant study}

\section{Total antioxidant capacity (TAC) assay}

The TAC of the plant extract was done following the method of [23] using ammonium molybdate reagent and the absorbance was measured at $695 \mathrm{~nm}$. TAC was expressed as $\mu \mathrm{g}$ ascorbic acid equivalent (AAE)/mg plant extract.

\section{DPPH assay}

The DPPH scavenging activity of the plant extracts was estimated using DPPH reagent and the absorbance read at $517 \mathrm{~nm}$ [24]. The scavenging activity of plant extract was calculated using the formula:
DPPH Scavenging activity $(\%)=\left[\frac{A b s \text { control }-A b s \text { sample }}{A b s \text { control }}\right] \times 100$

Abs control $=$ absorbance of DPPH and methanol.

Abs sample $=$ absorbance of DPPH and plant extract or ascorbic acid.

\section{FRAP assay}

FRAP assay was performed using TPTZ and $\mathrm{FeCl}_{3}$ reagents following the method of Benzie and Strain 1996 with slight modification as described by [25] and color developed was measured using spectrophotometer at $593 \mathrm{~nm}$. The FRAP activity of plant extracts was compared with the standard ascorbic acid.

\section{Heavy metal analysis}

Five essential elements-copper (Cu), zinc ( $\mathrm{Zn})$, cobalt (Co), manganese $(\mathrm{Mn})$ and iron (Fe) and three toxic elements such as lead $(\mathrm{Pb})$, chromium $(\mathrm{Cr})$ and cadmium $(\mathrm{Cd})$ of all the four plants were analyzed using atomic absorption spectrophotometer (AAS) following the method of [26]. Briefly, $0.5 \mathrm{~g}$ of each plant sample was digested with conc. $\mathrm{HNO}_{3}: \mathrm{HCl}(3: 1)$ at $85^{\circ} \mathrm{C}$ and kept overnight. This was followed by heating the mixture until the $\mathrm{NO}_{2}$ fumes ceased. Then conc. $\mathrm{HClO}_{4}(2 \mathrm{ml})$ was added. The solutions were filtered and diluted to $50 \mathrm{ml}$ of distilled water. The blank solution was taken as the same procedure. The samples were then analyzed in AAS (Perkin Elmer 3110).

\section{Statistical analysis}

All data are presented as means \pm standard deviation (SD) for at least three replications for each experiment. Calibration curves were prepared using a linear curve. Statistical analysis was performed using one-sample t-test. The results are considered to be significant at $P<0.05$.

\section{RESULTS AND DISCUSSION}

\section{Phytochemical analysis}

Plants are the natural source of biomolecules having numerous biological properties as medicine or nutrition. In fact, the various biological properties can be ascribed to the presence of various phytochemicals such as phenolics, terpenoids or alkaloids, etc [27]. Phytonutrients such as carbohydrates, fats, proteins etc. are the primary metabolites from which secondary metabolites such as phenolics, flavonoids etc. are derived. Several studies have associated the presence of secondary metabolites to the pharmacological potential of the plants [28].

Flavonoids are important secondary metabolite that possesses tremendous medicinal property such as antioxidant, antiinflammatory, anticancer, antibacterial, anti-viral activity etc [29]. The phytochemicals screening of methanolic extracts of $A$. calamus (MeAc), H. rosa-sinensis (MeHr), C. dactylon (MeCd) and E. floribundus (MeEf) showed high content of carbohydrates and proteins (table 1). Among all the plants, MeHr showed the highest quantity of carbohydrate $(386.22 \pm 6.44 \mu \mathrm{g} / \mathrm{mg}$ extract). Similarly, MeEf showed higher protein content $(310.40 \pm 11.44 \mu \mathrm{g} / \mathrm{mg}$ extract) among all the tested plants. Recent studies by Swargiary et al. [30] and Narzary et al. [31] also revealed a similar range of carbohydrate and protein content in the wild edible plants. Quantitative study of TPC showed highest concentration in MeEf $(245.66 \pm 9.68 \mu \mathrm{g} / \mathrm{mg}$ extract) followed by MeAc $(122.41 \pm 8.58 \mu \mathrm{g} / \mathrm{mg}$ extract), MeHr $(116.40 \pm 3.53 \mu \mathrm{g} / \mathrm{mg}$ extract) and MeCd $(63.60 \pm 5.77 \mu \mathrm{g} / \mathrm{mg}$ extract $)$, respectively. Flavonoid contents also showed higher in $\mathrm{MeHr}$ followed by MeEf, MeCd, and MeAc, respectively.

Antioxidant system is an important mechanism by which plants or animals can protect themselves from free radicals such as reactive oxygen species (ROS). Many diseases including diabetes, cancers etc. are directly or indirectly linked to ROS [32]. Our body has an innate capacity to neutralize most of the ROS called antioxidant property. The most significant pathway is the scavenging of free radicals in which free radical chain reactions are interrupted by phenolic compounds through its redox properties. In the present study, TPC, antioxidant activity by phosphomolybdate, DPPH and FRAP assay 
revealed higher activity in MeEf. MeHr showed lowest DPPH activity with $\mathrm{IC}_{50} 1750 \mu \mathrm{g}$. An increasing trend of FRAP activity was observed in a concentration-dependent manner in all the plants (fig. 1). The reducing potential of the tested extracts was observed over a concentration range $25-100 \mu \mathrm{g} / \mathrm{ml}$. The trend of reducing potential was significantly $(\mathrm{P}<0.05)$ lower than the standard ascorbic acid. Like other antioxidant activity, FRAP result also showed high activity in MeEf. Many studies have investigated the reducing power activity of several plants which showed an increasing trend of reducing power with the increase of plant concentrations $[33,34]$.

Table 1: Phytochemical content and IC $_{50}$ value DPPH assays of plant extracts

\begin{tabular}{|c|c|c|c|c|}
\hline Phytochemicals contents/IC I0 $_{5}$ values & C. dactylon & H. rosa-sinensis & E. floribundus & A. calamus \\
\hline Carbohydrates & $357.54 \pm 23.75$ & $386.22 \pm 6.44$ & $296.54 \pm 8.65$ & $331.68 \pm 28.20$ \\
\hline Protein & $213.60 \pm 9.14$ & $301.33 \pm 7.85$ & $310.40 \pm 11.44$ & $246.93 \pm 1.36$ \\
\hline TPC & $63.62 \pm 5.77$ & $116.4 \pm 3.53$ & $245.66 \pm 9.68$ & $122.41 \pm 8.58$ \\
\hline TFC & $6.84 \pm 0.92$ & $14.62 \pm 0.58$ & $12.77 \pm 0.33$ & $5.86 \pm 0.21$ \\
\hline TAA & $34.00 \pm 0.32$ & $45.41 \pm 1.95$ & $62.48 \pm 1.53$ & $39.50 \pm 0.73$ \\
\hline DPPH, $\mathrm{IC}_{50}(\mu \mathrm{g})$ & 930 & 1750 & 123.50 & 1170 \\
\hline
\end{tabular}

Values are expressed in mean \pm SD. All the calculations were represented as $\mu \mathrm{g} / \mathrm{mg}$ extract with three replications $(\mathrm{n}=3)$ for each experiment. The $\mathrm{IC}_{50}$ of standard ascorbic acid is $6.85 \mu \mathrm{g}$.

It is presumed that the reducing capacity of the extracts may function as an indicator of potential antioxidant activities through the action of breaking the free radical chain by donating hydrogen atom. Studies have revealed the presence of a strong relationship between TPC and TFC with antioxidant activity [34]. In the present study, we have also observed that the phenolic content have a significant correlation with the overall antioxidant properties of all the tested plants. However, the presence of total phenolic content showed poor correlation with the antioxidant property of plants.
Pearson correlation studies among the tested plants and their phytochemical contents, antioxidant activities showed both positive as well as negative correlation (table 2). The phytochemical contents i.e., phenolics and flavonoids showed good correlation with the antioxidant activities. A significant correlation was found between the TPC and TAA that indicates a strong dependence of overall antioxidant activity on the phenolic contents of the plant. Our result showed there is no significant correlation between the TPC and TFC with DPPH (negative correlation).
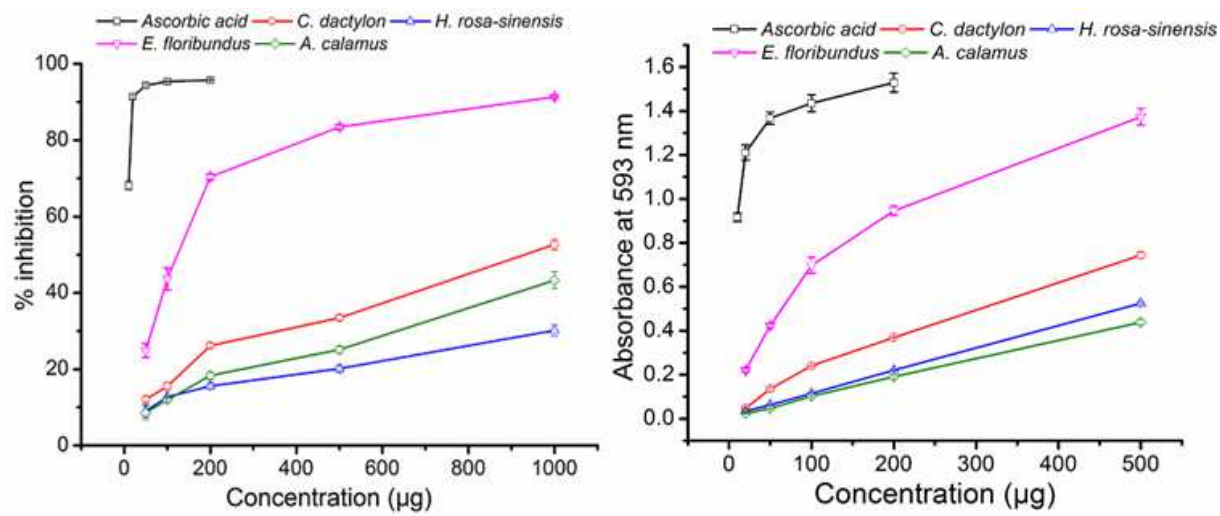

Fig. 1: DPPH activity of tested plants compared to (left) standard ascorbic acid and (right) increasing trend of FRAP activity with the increase of plant extract. All values are significantly different at $P<0.05$ compared to standard ascorbic acid

Table 2: Pearson correlation study of phytochemical and antioxidant activities of four plants

\begin{tabular}{|c|c|c|c|c|c|c|}
\hline & Carbohydrate & Protein & TPC & TFC & TAA & DPPH (IC $\left.{ }_{50}\right)$ \\
\hline Carbohydrate & 1 & -0.206 & -0.775 & 0.145 & -0.632 & 0.909 \\
\hline Protein & -0.206 & 1 & 0.775 & 0.891 & 0.865 & -0.129 \\
\hline TPC & -0.775 & 0.775 & 1 & 0.498 & $0.974^{*}$ & -0.693 \\
\hline TFC & 0.145 & 0.891 & 0.498 & 1 & 0.673 & 0.063 \\
\hline TAA & -0.632 & 0.865 & $0.974^{*}$ & 0.673 & 1 & -0.608 \\
\hline $\mathrm{DPPH}\left(\mathrm{IC}_{50}\right)$ & 0.909 & -0.129 & -0.693 & 0.063 & -0.608 & 1 \\
\hline
\end{tabular}

*Correlation is significant at the $P<0.05$ level ( $\mathrm{n}=4$ numbers of plants).

\section{Elemental analysis}

Trace elements are a group of naturally occurring elements that are required for various biochemical and physiological functions. Inadequate supply of these micro-nutrients results in a variety of deficiency diseases or syndromes [6,8]. Our study revealed the presence of various essential and toxic elements in the test samples. In the present study, various essential elements like $\mathrm{Cu}, \mathrm{Zn}, \mathrm{Co}, \mathrm{Mn}$, and $\mathrm{Fe}$ were also found to be present in the samples of plant collected from different sites, however, all the toxic elements were found to be within the World Health Organization permissible limits [6]. Elemental analysis and the contents of all the four test plants namely, A. calamus, H. rosa-sinensis, C. dactylon and E. floribundus are given in table 2. Concentrations of various essential elements $(\mathrm{Cu}$, $\mathrm{Zn}, \mathrm{Co}, \mathrm{Mn}$ and $\mathrm{Fe}$ ) and toxic elements $(\mathrm{Pb}, \mathrm{Cd}$, and $\mathrm{Cr}$ ) were analyzed by AAS. Out of the five essential elements such as $\mathrm{Cu}, \mathrm{Zn}$, $\mathrm{Co}, \mathrm{Mn}$, and $\mathrm{Fe}$, the highest elemental content was found to be $\mathrm{Mn}$ $(1.87 \pm 0.02 \mu \mathrm{g} / \mathrm{g}$ powder $)$ in $H$. rosa-sinensis followed by $\mathrm{Fe}$ 
$(1.71 \pm 0.09 \mu \mathrm{g} / \mathrm{g}$ powder $)$ and $\mathrm{Cu}(0.51 \pm 0.22 \mu \mathrm{g} / \mathrm{g})$ in A. calamus, respectively. The presence of cobalt was detected to be lowest $(0.06 \pm 0.01 \mu \mathrm{g} / \mathrm{g}$ powder) in A. calamus among all the tested plants. $\mathrm{Cu}$ was found to be highest in A. calamus while $\mathrm{Zn}$ and Co showed the highest concentration in $C$. dactylon. Subsequently, the content of $\mathrm{Mn}$ and Fe were highest in H. rosa-sinensis and E. floribundus. And the content of $\mathrm{Cu}$ ranged from a minimum of $0.04 \mu \mathrm{g} / \mathrm{g}$ to $0.244 \mu \mathrm{g} / \mathrm{g}$ in $H$. rosa-sinensis and for A. calamus the range was 0.12 to 1.809 $\mathrm{mg} / \mathrm{g}$. Cu is an essential enzymatic element for normal plant growth and development, but it can also be toxic at excessive levels [35]. Likewise, $\mathrm{Zn}$ ranged from a minimum 0.035 to $0.139 \mu \mathrm{g} / \mathrm{g}$ in $A$. calamus to a maximum 0.519 to $0.906 \mu \mathrm{g} / \mathrm{g}$ in C. dactylon. $\mathrm{Zn}$ is also an essential trace element for plant growth and it also plays an important role in various cell processes, including normal growth, brain development, behavioral response, bone formation and wound healing [35]. The dietary limit of Zn has been set as $100 \mathrm{ppm}$. The presence of metallic compounds at a certain concentration is beneficial to plants and animals as well [36]. Pb was found to be highest with $0.60 \pm 0.11 \mu \mathrm{g} / \mathrm{g}$ of plant powder in $\mathrm{H}$. rosa-sinensis. Similarly, $\mathrm{Cr}$ and $\mathrm{Cd}$ were found to be highest in $C$. dactylon and $A$. calamus, respectively. $\mathrm{Cr}$ was found to be lowest among all the tested elements. All the tested plants showed a significant difference in the concentration of the metal contents among the plants. However, statistically, no significant differences were detected in the concentration of $\mathrm{Cr}$ among all the four anthelmintic plants (table 3). Like many biological molecules metals serve either as cofactors and activator of enzyme reactions forming enzymes/substrate metal complex, exert a catalytic property such as a prosthetic group in metalloproteins or regulators of nerve transmission, muscle contraction, osmotic pressure and salt-water balance [37]. On the other hand, heavy metals like arsenic, cadmium, chromium, lead, and mercury do not have any beneficial biological role and are known to be systemic toxicant that induces multiple organ damages [8].

Table 3: Trace element concentration (in $\mu \mathrm{g} / \mathrm{g}$ ) of four anthelmintic plants

\begin{tabular}{|c|c|c|c|c|c|c|c|c|}
\hline \multirow{2}{*}{$\begin{array}{l}\text { Elements } \\
(\mu \mathrm{g} / \mathrm{g} \text { extract })\end{array}$} & \multicolumn{5}{|c|}{ Essential elements } & \multicolumn{3}{|l|}{ Toxic metals } \\
\hline & $\mathrm{Cu}$ & Zn & Co & Mn & $\mathbf{F e}$ & $\mathbf{P b}$ & $\mathrm{Cr}$ & Cd \\
\hline A. calamus $^{\mathrm{a}}$ & $0.51 \pm 0.22^{\mathrm{b}, \mathrm{c}, \mathrm{d}}$ & $0.10 \pm 0.01^{b, c, d}$ & $0.06 \pm 0.01^{b, c, d}$ & $0.37 \pm 0.10^{\mathrm{b}, \mathrm{c}, \mathrm{d}}$ & $0.53 \pm 0.10^{\mathrm{b}, \mathrm{c}, \mathrm{d}}$ & $0.06 \pm 0.10^{b}$ & $0.02 \pm 0.01$ & $0.35 \pm 0.09^{b, c, d}$ \\
\hline H. rosa-sinensis ${ }^{\mathrm{b}}$ & $0.17 \pm 0.02^{\mathrm{a}, \mathrm{c}, \mathrm{d}}$ & $0.42 \pm 0.02^{\mathrm{a}, \mathrm{c}, \mathrm{d}}$ & $0.10 \pm 0.01^{\mathrm{a}, \mathrm{c}, \mathrm{d}}$ & $1.87 \pm 0.02^{\mathrm{a}, \mathrm{c}, \mathrm{d}}$ & $0.81 \pm 0.04^{\mathrm{a}, \mathrm{c}, \mathrm{d}}$ & $0.60 \pm 0.11^{\mathrm{a}, \mathrm{c}, \mathrm{d}}$ & $0.01 \pm 0.01$ & $0.02 \pm 0.01^{\mathrm{a}}$ \\
\hline C. dactylon ${ }^{\mathrm{c}}$ & $0.13 \pm 0.03^{\mathrm{a}, \mathrm{b}, \mathrm{d}}$ & $0.77 \pm 0.024^{\mathrm{a}, \mathrm{b}, \mathrm{d}}$ & $0.16 \pm 0.01^{\mathrm{a}, \mathrm{b}, \mathrm{d}}$ & $0.95 \pm 0.03^{\mathrm{a}, \mathrm{b}, \mathrm{d}}$ & $0.17 \pm 0.03^{\mathrm{a}, \mathrm{b}, \mathrm{d}}$ & $0.07 \pm 0.02^{b}$ & $0.03 \pm 0.01$ & $0.02 \pm 0.09^{a}$ \\
\hline E. floribundus ${ }^{\mathrm{d}}$ & $0.15 \pm 0.03^{\mathrm{a}, \mathrm{b}, \mathrm{c}}$ & $0.38 \pm 0.16^{\mathrm{a}, \mathrm{b}, \mathrm{c}}$ & $0.05 \pm 0.02^{\mathrm{a}, \mathrm{b}, \mathrm{c}}$ & $0.73 \pm 0.23^{\mathrm{a}, \mathrm{b}, \mathrm{c}}$ & $1.71 \pm 0.09^{\mathrm{a}, \mathrm{b}, \mathrm{c}}$ & $0.03 \pm 0.02^{b}$ & $0.02 \pm 0.01$ & $0.06 \pm 0.02^{\mathrm{a}}$ \\
\hline
\end{tabular}

Data are expressed as mean \pm SEM, values are significantly different at $P \leq 0.05$, superscript $\mathrm{a}, \mathrm{b}, \mathrm{c}$, and d indicates the statistical significance of the plants. All experiments were carried out in triplicates $(n=3)$.

\section{CONCLUSION}

The presence of phytochemicals such as total proteins, carbohydrates, phenolics and flavonoids in A. calamus, $H$. rosasinensis, C. dactylon and E. floribundus provides scientific evidence for the pharmacological significance of the plants and also accounts for a good source of phytonutrients. The presence of high phenolic, flavonoid compounds, and vit.-C could be attributed to its pharmacological activity associated with free radical scavenging activity. Furthermore, antioxidant study by total antioxidant activity, DPPH, FRAP, and TBARS also showed the high potential of scavenging free radicals. The presence of high quantities of essential trace elements and below the permissible range of toxic elements offers a better possibility of the use of the tested plants as medicines. The present data, therefore, would certainly help to ascertain the potency of the tested parts of the plants for medicinal use and functional food and nutraceuticals applications as well. However, in-depth investigations need to be carried out to isolate and identify the active components of the plants and to explore its mechanisms of action as well as their potential role in biological activity and antioxidant activities as well.

\section{CONFLICT OF INTERESTS}

Declared none

\section{REFERENCES}

1. Roy Choudhury P, Dutta Choudhury M, Ningthoujam SS, Das D, Nath D, Das Talukdar A. Ethnomedicinal plants used by traditional healers of North Tripura district, Tripura, North East India. J Ethnopharmacol 2015;166:135-48.

2. Pham-Huy LA, He H, Pham-Huy C. Free radicals, antioxidants in disease and health. Int J Biomed Sci 2008;4:89-96.

3. Krinsky NI. Mechanism of action of biological antioxidants. Proc Soc Exp Biol Med 1992;200:248-54.

4. Lobo V, Patil A, Phatak A, Chandra N. Free radicals, antioxidants and functional foods: Impact on human health. Pharmacogn Rev 2010;4:118-26.

5. Prashanth L, Kattapagari KK, Chitturi RT, Baddam VRR, Krishna Prasad L. A review on the role of essential trace elements in health and disease. J Dr. NTR University Health Sci 2015;4:7585.

6. WHO/FAO/IAEA. World Health Organization. Switzerland: Geneva; Trace Elements in Human Nutrition and Health; 1996.
7. Castro-Gonzalez MI, Mendez-Armenta M. Heavy metals: implications associated to fish consumption. Environ Toxicol Pharmacol 2008;26:263-71.

8. Tchounwou PB, Yedjou CG, Patlolla AK, Sutton DJ. Heavy metals toxicity and the environment. EXS 2012;101:133-64.

9. Nath P, Yadav AK. Anticestodal properties of Hibiscus rosasinensis L. (Malvaceae): an in vitro and in vivo study against Hymenolepis diminuta (Rudolphi, 1819), a zoonotic tapeworm. J Parasit Dis 2016;40:1261-5.

10. Nath P, Yadav AK. Anthelmintic activity of a standardized extract from the rhizomes of Acorus calamus Linn. (Acoraceae) against experimentally induced cestodiasis in rats. J Intercult Ethnopharmacol 2016;5:390-5.

11. Nath P. Evaluation of anthelmintic activity of some medicinal plants used in the folklore medicine system of Riang tribe in Tripura. Ph. D. Thesis, Department of Zoology. Shillong: North Eastern Hill University; 2014. p. 284.

12. Sharma V, Singh I, Chaudhary P. Acorus calamus (The Healing Plant): A review on its medicinal potential, micropropagation, and conservation. Nat Prod Res 2014;28:1454-66.

13. Kim WJ, Hwang KH, Park DG, Kim TJ, Kim DW, Choi DK, et al. Major constituents and antimicrobial activity of Korean herb Acorus calamus. Nat Prod Res 2011;25:1278-81.

14. Liu CX, Zhou LG, Liu ZL, Du SS. Identification of insecticidal constituents of the essential oil of Acorus calamus rhizomes against Liposcelis bostrychophila Badonnel. Molecules 2013;18:5684-96.

15. Jadhav VM, Thorat RM, Kadam VJ, Sathe NS. Traditional medicinal uses of Hibiscus rosa-sinensis. J Pharm Res 2009;2:1220-2.

16. Annapurna HV, Apoorva B, Ravichandran N, Arun KP, Brindha $\mathrm{P}$, Swaminathan S, et al. Isolation and in silico evaluation of anti-diabetic molecules of Cynodon dactylon (L.). J Mol Graph Model 2013;39:87-97.

17. Utami R, Khalid K, Sukari MA, Rahmani M, Abdul AB, Dachriyanus. Phenolic contents, antioxidant and cytotoxic activities of Elaeocarpus floribundus Blume. Pak J Pharm Sci 2013;26:245-50.

18. Sadasivam S, Manickam. Biochemical methods. 3rd Edition. New Delhi: New Age International; 2008. 
19. Lowry $\mathrm{OH}$, Rosebrough NJ, Farr AL, Randall RJ. Protein measurement with the folin phenol reagent. J Biol Chem 1951;193:265-75.

20. Iloki S, Lewis L, Rivera G, Gil A, Acosta A, Meza C, et al. Effect of maturity and harvest season on antioxidant activity, phenolic compounds and ascorbic acid of Morinda citrifolia L. (Noni) grown in Mexico. Afr J Biotechnol 2013;12:4630-9.

21. Ordonez AAL, Gomez JD, Vattuone MA, Isla MI. Antioxidant activities of Sechium edule (Jacq). Food Chem 2006;97:452-8.

22. Huda-Faujan N, Noriham A, Norrakiah AS, Babji AS. Antioxidant activity of plants methanolic extracts containing phenolic compounds. Afr J Biotechnol 2009;8:484-9.

23. Mamta, Mehrotra S, Amitabh Kirar V, Vats P, Nandi SP, Negi PS, et al. Phytochemical and antimicrobial activities of Himalayan Cordycep ssinensis (Berk.) Sacc. Indian J Exp Biol 2015;53:3643.

24. Iloki Assanga SB, Lewis Luján LM, Lara Espinoza CL, Gil Salido AA. Solvent effects on phytochemical constituent profiles and antioxidant activities, using four different extraction formulations for analysis of Bucida buceras $\mathrm{L}$. and Phoradendron californicum. BMC Res Notes 2015;8:396.

25. Welz B, Sperling M. Atomic absorption spectroscopy. WileyVCH Verlag Gmbh, Weinheim; 1999. p. 614-47.

26. Mahapatra AK, Mishra S, Basak UC, Panda PC. Nutrient analysis of some selected wild edible fruits of deciduous forests of India: An explorative study towards non-conventional bio-nutrition. Adv J Food Sci Technol 2012;4:15-21.

27. Patra B, Schluttenhofer $\mathrm{C}, \mathrm{Wu}$ Y, Pattanaik S, Yuan L. Transcriptional regulation of secondary metabolite biosynthesis in plants. Biochim Biophys Acta 2013;1829:1236-47.

28. Kumar S, Pandey AK. Chemistry and biological activities of flavonoids: an Overview. Sci World J 2013. http://dx.doi.org/10.1155/2013/162750.

29. Swargiary A, Daimari A, Daimari M, Basumatary N, Narzary E. Phytochemicals, antioxidant, and anthelmintic activity of selected traditional wild edible plants of lower Assam. Indian J Pharmacol 2016;48:418-23.

30. Narzary H, Swargiary A, Basumatary S. Proximate and vitamin-C analysis of wild edible plants consumed by Bodos of Assam, India. J Mol Pathophysiol 2015;4:128-33.

31. Kumpulainen JT, Salonen JT. Natural antioxidants and anticarcinogens in nutrition, health, and disease, The Royal Society of Chemistry, UK; 1999. p. 178-87.

32. Kibiti CM, Afolayan AJ. Preliminary phytochemical screening and biological activities of Bulbine abyssinica in the folk medicine in the Eastern Cape Province, South Africa. J Evidence-Based Complementary Altern Med 2015. http://dx.doi.org/10.1155/2015/617607

33. Padalia $\mathrm{H}$, Moteriya $\mathrm{P}$, Satasiya $\mathrm{R}$, Chanda $\mathrm{S}$. In vitro free radical scavenging activity and phenol and flavonoid content of Nerium indicum, Pelto phorampterocarpum and Rosa spps. flower extracts. Asian J Pharm Clin Res 2015;8:91-7.

34. Sitorus P, Hasibuan P, Satria D. Total phenolic and flavonoid contents and antioxidant activity of ethanol fraction of Picria fel-terrae (Lour.) herbs. Asian J Pharm Clin Res 2017;10:243-5.

35. Moscow S, Jothiven KK. Study on the mineral content of some ayurvedic Indian medicinal plants. Int J Pharma Sci Res 2012;3:294-9.

36. Wintz H, Fox T, Vulpe C. Functional genomics and gene regulation in biometals research. Biochem Soc Transactions 2002;30:766-8.

37. Ozcan MM, Akbulut M. Estimation of minerals, nitrate, and nitrite contents of medicinal and aromatic plants used as spices, condiments, and herbal tea. Food Chem 2008;106:852-8.

\section{How to cite this article}

- Ananta Swargiary, Purobi Nath, Bihung Basumatary, Dulur Brahma. Phytochemical, antioxidant, and trace element analysis of anthelmintic plants of North-East India. Int J Pharm Pharm Sci 2017;9(9):228-232. 